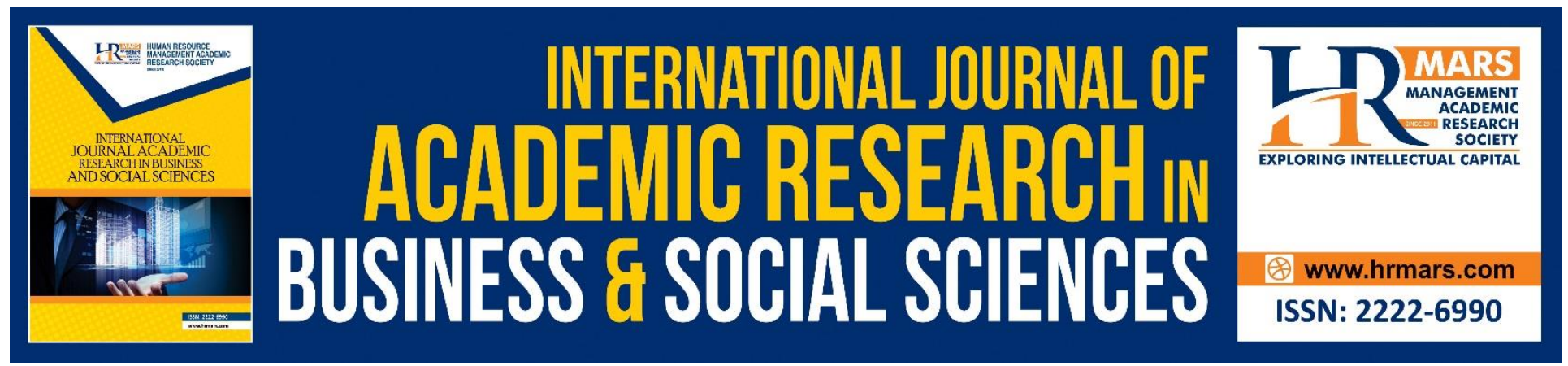

\title{
Malaysian Political Engagement 1945-2013
}

\author{
Ishak Saat, Mohd Kasri Saidon, Ruhaizan Sulaiman
}

To Link this Article: http://dx.doi.org/10.6007/IJARBSS/v9-i2/5524

DOI: $\quad 10.6007 /$ IJARBSS/v9-i2/5524

Received: 17 Jan 2019, Revised: 13 Feb 2019, Accepted: 02 March 2019

Published Online: 03 March 2019

In-Text Citation: (Saat, Saidon, \& Sulaiman, 2019)

To Cite this Article: Saat, I., Saidon, M. K., \& Sulaiman, R. (2019). Malaysian Political Engagement 1945-2013. International Journal of Academic Research in Business and Social Sciences, 9(2), 93-105.

\section{Copyright: (C) 2019 The Author(s)}

Published by Human Resource Management Academic Research Society (www.hrmars.com)

This article is published under the Creative Commons Attribution (CC BY 4.0) license. Anyone may reproduce, distribute, translate and create derivative works of this article (for both commercial and non-commercial purposes), subject to full attribution to the original publication and authors. The full terms of this license may be seen at: http://creativecommons.org/licences/by/4.0/legalcode

Vol. 9, No. 2, 2019, Pg. 93 - 105

Full Terms \& Conditions of access and use can be found at http://hrmars.com/index.php/pages/detail/publication-ethics 


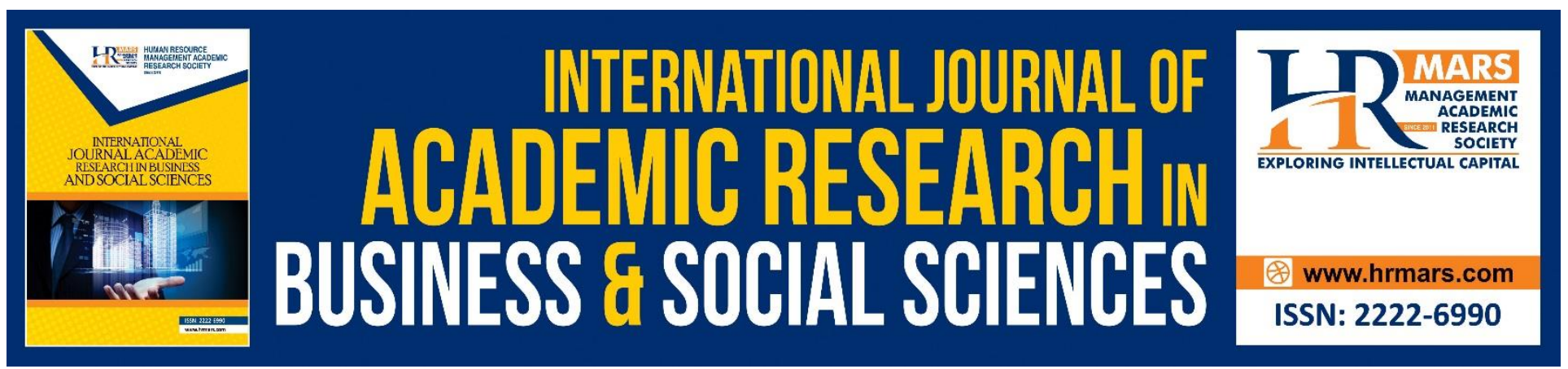

\title{
Malaysian Political Engagement 1945-2013
}

\author{
Ishak Saat \\ Universiti Pendidikan Sultan Idris \\ Mohd Kasri Saidon \\ Universiti Utara Malaysia \\ Ruhaizan Sulaiman \\ Universiti Sultan Zainal Abidin
}

\begin{abstract}
In the history of Malaysia's politics, consensus is an approach adopted by all political parties. In order to obtain people's support, political co-operation is a norm between various political parties despite having different ideologies and goals. For the sake of the country's well-being, differences are set aside with the ultimate goal of getting a political mandate and power of government. In fact, political co-operation is adopted and prioritized even before independence, in the post-independence and in the new millennium. By analysing historical documents and political party files, this article wishes to unleash the history of political collaboration and co-operation undertaken by all political parties in Malaysia. Finally, political understanding and co-operation between political parties has been successful in ensuring that social harmony and national integration be achieved and also to ensure that a new Malaysia can be realized.
\end{abstract}

Keywords: Consensus, Barisan Nasional, Barisan Altenatif, Pakatan Rakyat and Racial Unity.

\section{Introduction}

The emergence of a multiracial society in Malaysia before the First World War produced various racial-based welfare organizations. This scenario affected the political landscape as early as the 20th century in Malaysia, although originally, the emergence of the welfare of every immigrant community was only to guarantee the safety and the livelihood of each other. In addressing their political issues, they were more blessed with their home country. Political scenarios in their home country would influence the formation of political gatherings amongst them. However, even they were seen as a race but political flows were grouped according to the ideology, for example, the Chinese had two major political influences affecting the Chinese community in Malaya. The nationalist was under the influence of Koumintang or Communist Party under the umbrella of the Chinese Communist Party (CCP). Likewise, for the Indian community, the Muslims were under the leadership of Muhammad Ali 
Jinnah, the influence of Indian nationalists which was under the stature of Jawahal Nehru or Mathma Ghandi and the socialist stream under the leadership of Subha Chandra Bose. The Malays were grouped into ideologies namely Islam, nationalist, socialist or communist. But the diversity of political aristocracy had never hindered political co-operation amongst them.

\section{Political Consensus Background}

During the Post World War II, geopolitics in Malaya were increasingly challenging and growing, most colonized nations were bolder to fight for independence and some had begun independence. In example, India achieved its independence in 1947 and Indonesia in 1945 and later in 1949. The emergence of independent nations was based on the four prerequisites of the formation of the country main conditions namely government, people, sovereignty and borders. Citizenship formation makes the position of immigrants at the crossroads. The issue of citizenship was a big issue that needed to be understood and best explained. They worried about their positions, considering whether they had to return to their home country or to choose to stay overseas? If they chose to continue living overseas, they would lose their citizenship rights. Many of them decided to return to their home country. But some decided to continue living in Malaya. This great decision also influenced their political struggle so that they would participate in the struggle for independence to guarantee the right of citizenship when Malaya achieved its independence.

That was the reason to why the political landscape in Malaya has changed. Immigrants were keen to participate in the struggle for independence to secure their future in Malaya. Political party leaders saw the significance of the consensus being realized. Political collaboration must be wisely implemented for the independence of Malaya. For the harmony of Malaya, it must be taken seriously and as good as possible. Based on the tolerance of racial politics, various levels of political leadership began to step forward to realize this noble goal.

At that time, Malaysian diversity of various races such as Malays, Chinese, Indians, Iban, Khadazan, Bajau, Dayak and others caused the political parties in Malaysia be surrounded by racistbased struggle. The base of the struggle could be considered narrow and critical if it was not rationally driven and opened. After the Second World War until Malaya had achieved its independence, the Malays and non-Malays sought to create political convergence such as the political co-operation between the Pusat Tenaga Rakyat (PUTERA) and the 1947 Malayan Council of Joint Action (AMCJA),( Othman, 2000:310-313) the United Malay National Organization (UMNO) with the Malayan Chinese Association (MCA) and then the Malayan India Congress (MIC) formed the 1949 PERIKATAN and the Labor Party of Malaya with the People's Party of Malaya (PBM-PRM) formed the SOCIALIST FRONT in 1955 (Sulaiman, 1988:64) After independence, the opposition coalition like the The Democratic Action Party (DAP) and Parti Keadilan Rakyat (PKR) formed the BARISAN ALTERNATIF (BA) in 1999. Furthermore, the opposition political cooperation was reunited between the SeMalaysia Islamic Party (PAS), the Democratic Action Party (DAP) and the Parti Keadilan Rakyat (PKR) forming a Pakatan Rakyat (PR) in 2008. The latest was in 2015, where there was a new political opposition coalition between Parti Keadilan Rakyat (PKR), Parti Amanah Negara (AMANAH) and Democratic Action Party (DAP) under the name of PAKATAN HARAPAN. The history of political affiliation in Malaysia is unique 
and confronts with the challenges of the modern world. The demands of open society have preceded the interests of their respective races.

\section{PUTERA-AMCJA Consensus 1947}

The first political affiliation in Malaya was among PUTERA-AMCJA in 1947. It illustrated an intimacy between races. PUTERA organised the Left Movement of Malaya Conference at the MNP headquarters in Batu Road, Kuala Lumpur on 22 February 1947. In the union, the majority of the organizations belonged to PUTERA which came from the state of Perak or erected in Perak, such as Malay Nationalist Party (MNP), Angkatan Pemuda Insaf (API), Angkatan Wanita Sedar (AWAS), Gerakan Angkatan Muda (GERAM), Barisan Tani seMalaya (BATAS) and also Hizbul Muslimin. This combination was needed in order to empower the left movement in Malaya. Given that the Chinese political movement was against the British colonizers, PUTERA was thinking of the need to create a political alliance between them. The All-Malayan Council of Joint Action (AMCJA) is a coalition of the leftist Chinese movements. These views and measures proved that multi-racial political cooperation has been initiated by the leftists in the political affairs of Malaya. Political consensus PUTERA-AMCJA succeeded in raising the colonialists, that the people of all races can unite in order to move forward. The idea of Malayan Union and the Federation of Malaya organized by British colonialists was opposed by PUTERA-AMCJA. Consequently, they gave a constitution called the People's Constitution in 1947. The picture of this political affiliation was the first attempt by the Malays and non-Malays to demolish the separating walls between them. But this cooperation was not approved by the British as they sought independence. In other words they wanted to be self-governing, which meant to get rid of the British from the land of Malaya. Hence, this political co-operation had been difficult and had no support from British colonists because it was labelled as radical or leftist (Saat.2015:12)

According to Mohd. Isa Othman, a coalition of PUTERA-AMCJA was not merely a coalition of political organizations but it showed the cooperation of Malay political organizations with nonMalays for the first time. PUTERA (Othman, 2000:333-334) took the approach of working with Chinese organizations to take on Malayan Union's challenge. This collaboration and cooperation strategy proved the maturity of the leftist political parties. PUTERA which was led by PKMM diversified its political strategy in order to convey information and message of struggle. Hence, they used newspapers to fend off the spirit and spread their information to champion independence through the newspaper Suara Rakyat and Voice of the People.

The political agreement of PUTERA-AMCJA conveyed the idea of the People's Constitution, recognized by many as the best constitutional proposal at that time. This constitution was the result of a three-day discussion between Dr. Burhanuddin Al Helmy, Ishak Hj. Muhammad, Tan Cheng Lock, J. A. Thivy, Ahmad Boestamam, Chan Loo and Gerald de Cruz. (CO537/2140/136697 Secret HQ Malaya Command ,1946:2) The constitutional proposal was a proposal received by all nations in their affiliation. This People's Constitution was proposed to replace the Malayan Union which created a great controversy in Malaya in 1946. The ten (10) principles that constituted the Constitution of the People were: 
1. Singapore should be united with Malaya.

2. A central government and state councils were elected.

3. The Malay rulers would have the real power, responsible to the people through the Council.

4. A new constitution for Malaya, providing certain privileges for the advancement of the Malays in terms of politics and economics.

5. Malay customs and Islam were fully controlled by the Malays through the Special Council.

6. A common nationality of all people who regarded Malaya as a permanent residence and willing to devote their allegiance indefinitely.

7. Malay Language should be the only National Language and official language for Malaya.

8. The defense and foreign affairs should be the sole responsibility of the Malayan and British governments.

9. Malaya citizenship should be named Malays.

10. White and red should be included as the background of the national flag of Malaya. (Exposition To The Amended Draft of the New Constitution)

This constitutional proposal was the first attempt by the leftist group to set up their own government (Stockwell.1979:93), where it also would merge Malaya and Singapore, and would also adopting the law in the name of the Malays. Since the People's Constitution was proposed by the leftist group then it was rejected by the British. This rejection was repaid by a hartal on October 20, 1947. (Ishak Saat.2010:65) The strike was supported by the Malayan Democratic Union (MDU), the MIC, the Pan Malayan Federation of Trade Union (PMFTU) and the Associated Chinese Chambers of Commerce (ACCC). A quote in Times of Malaya and Straits echoed:

"The executive Bureau of the Pan Malayan Federation of Trade Union yesterday issued a lengthy manifesto supporting the Malaya-wide hartal called by PUTERA at the All-Malayan Council of Joint Action on Oct-20 in protest against the Revised Constitutional Proposals." (Times of Malaya and Straits Echo.14/10/1947:3)

But this strike was also fail to change the British stand. The failure of PUTERA-AMCJA political coordination had subsequently resulted in a new consensus on the name of PERIKATAN in 1949. 


\section{Permuafakatan Perikatan}

Recognizing the importance of multiracial political cooperation, UMNO under the leadership of Tunku Abdul Rahman Putra Al Haj sought to establish a multi-racial political organization in 1949. Tunku Abdul Rahman's leadership began to consider the need to create a multi-racial political cooperation in order to curb the spread of racial politics in Malaya. Therefore, PERIKATAN is formed. In a political talk organized by the Socialist Club of Universiti Malaya, Kuala Lumpur on March 17, 1951, Tunku Abdul Rahman explained the purpose of PERIKATAN:

"About what will happen when we accept responsibility then I want to tell you gentlemen, first we have to overcome all the bad feelings like the feeling of inferiority complex. If not, then we can't achieve our goals. We must venture towards independence. " (Tunku Abdul Rahman Speech.17/3/1951)

Add Tunku:

"We will demand a committee to study the constitution of the Federation of Malaya now and to make recommendations to change the constitution in preparation for our new government and independence." (Tunku Abdul Rahman Speech. 17/3/1951)

According to Tunku Abdul Rahman, when the concept of power sharing introduced by UMNO through PERIKATAN could be accepted by the general public, it would easily be adopted by the multiracial society in Malaya. This success brought UMNO's name into multi-racial political co-operation. This strategy helped to undermine PKMM and strengthened PERIKATAN. This demonstrated the maturity of Tunku Abdul Rahman Putra Al-Haj in politics, through the view of Ramlah Adam (1999:xxviii)

The uniqueness and political maturity of PERIKATAN were very different from the Malay radicals. The failure in political cooperation of PUTERA-AMCJA in 1947 changed the AMCJA political approach. AMCJA made a political transformation by changing into the Malayan Chinese Association (MCA) and made a drastic decision to join PERIKATAN, which was before their traditional enemy. They used the Yacht symbol. The party managed to gain support from various races in Malaya. Dato' Onn Jaafar's role in uniting the Malays should always be appreciated, but his attempt to open UMNO membership to a multi-racial party was strongly opposed by UMNO's own members. This incident led to a tragedy of Dato Onn leaving UMNO, the party he directly involved in its establishment. On 26 August 1951, Dato Onn Jaafar officially withdrew from joining UMNO. However Tunku Abdul Rahman's approach was different from Dato Onn's. Tunku thought that opening Umno membership to immigrants was a less appropriate move but combining UMNO with non-Malay parties was more realistic. It was really a matured political consensus hence resulting PERIKATAN.

Realizing the fact that it was rather difficult to gain independence for the Malays alone at that time, Tunku Abdul Rahman and UMNO then worked together to bring the other non-Malay parties to also fight for independence. This PERIKATAN was portrayed in the Kuala Lumpur City Council 
elections in 1952. In this municipal election, the PERIKATAN got a big win. This also attracted the interest of the Malayan Indian Congress (MIC) to participate in PERIKATAN. PERIKATAN again for the second time needed to undergo a hard time in the first General Election in Malaya on July 27, 1955. However, PERIKATAN managed to unleash the trials by winning 51 of the 52 seats. This winning gave PERIKATAN an opportunity to form a government. Tunku Abdul Rahman Putera Al-Haj was appointed as the first Chief Minister. He then formed a multi-racial cabinet. The concept of the coalition has highlighted the roles of Tunku Abdul Rahman, Tun Tan Cheng Lock and Tun Sambanthan in giving birth to an independent nation later, especially through the concept of power sharing and social contracts. It could not be denied that this understanding and agreement between previous leaders with multi-racial political co-operation and taking into account the position of the Malays as the son of the soil, this unity of thought must be nurtured and protected. It must be maintained to ensure harmony and racial unity for the sake of beloved Malaysia.

Various political compromises were made by PERIKATAN members. With reference to the PERIKATAN Constitution, there were new goals that were mutually agreed as the following:

1. Establish, protect and uphold the principles of democracy of Parliament in Malaya.

2. The position of the Raja Melayu as constitutional leader in their respective states, would be defended.

3. Promote and maintain harmony and racial pride and protect the rights of the majority.

4. To establish and maintain the unity of the Malayan Nations.

5. To improve the living conditions and welfare of Malaya people.

6. To achieve other goals from time to time that will pursue the interests of the population and the country as a whole. (Fail UMNO/SUA 154/56)

By referring to the PERIKATAN Constitution Documents, it was noted that they agreed to adopt the BANGSA MALAYAN BERSATU for all people of Malaya. This is a political agreement between the Malays, Chinese and India, such in the People's Constitution proposed by PUTERA-AMCJA in 1947, adopted Malay as citizenship. Thus this establishment was a form of a new compromise in interethnic politics in Malaya at that time. For what had been decided, it can be concluded that immigrants were willing to change their stance in order to achieve greater goals which was the question of citizenship and independence of Malaya. The success of PERIKATAN with their big coalition, namely UMNO, MCA and MIC, and won the first election made the coalition to be accepted by the people of Malaya irrespective of races. Consequently, PERIKATAN in the Testemant "Mandate" (AMANAT) POLITIK PERIKATAN and later translated as their memorandum to the Reid Commission had proposed several matters: 
"Some of the (Testaments) we have mentioned below illustrate the strong will of the greatest number of the people of this country to establish a kingdom that will guarantee the freedom, equality and unity of the new nation. Therefore we wish that the upcoming Merdeka would allow its people to observe the free and equitable way of living. This constitution must also provide a condition to create a strong government and to guarantee the goodness and convenience of all its people." (Fail UMNO/SUA No. 28A/1957)

In the AMANAT POLITIK PERIKATAN, there was a collective agreement in order to achieve independence. But there was also a conflict of opinion when discussing the question of Malaya after independence, what was the right name for this independent country? UMNO proposed Malaysia as the name of the new country while MCA proposed it to be called as Malaya. But the contradiction did not lead to disputes or separations. One of the most interesting things was that the breakdown of the privileges of the Malays and Islam as the official religion for Malaysia were accepted by all parties in PERIKATAN provided that the rights of other races were also guaranteed by the constitution. Finally to fulfill the satisfaction of all parties, the principle of Jus Soli citizenship were accepted by all. However, there were some prerequisites for Jus Soli that should be considered appropriately so that the general Malay community could accept the citizenship grant based on this concept.

Among the conditions proposed by PERIKATAN in the transitional period were:

1. Had been born here and were 18 years of age or older.

2. Good behavior.

3. Swear to be loyal and deprive loyalty to any nation or nation.

4. Make the pledge that they intend to stay here permanently.

5. Has been in the country for five years from the previous seven years prior to their application.

6. Acquire basic Malay language (Ibrahim, 2004:176-177)

One of the most important things in political affiliation in Malaysia was the question of citizenship. It would be a future guarantee that everyone would have a nationality, with the aim to ensure a safer and more secure future. Therefore, every political affiliation in Malaysia could not escape from agreeing on the question of citizenship to be owned by Malaysians. The political collusion of this PERIKATAN would finally make Malaya achieving its independence on August 31, 1957. 
Malaya, under the leadership of Tunku Abdul Rahman continued to advance the nation in line with international political developments. The idea to form a bigger country was agreed, therefore on September 16, 1963, Sabah, Sarawak and Singapore joined Malaya to forming a new country named MALAYSIA. (The Sunday Times. 29/5/1962:1) A greater and more regional political consensus. The proposals proposed by Tunku Abdul Rahman then received encouraging response and thus gained broad coverage within and outside the country. (Berita Harian.4/6/1961:1) It is not just a suggestion but it is followed by the setting up of the Melayu Raya Consultative Committee which consists of states such as the Federation of Malaya, Singapore, Sabah, Sarawak and Brunei chaired by Donald Stephens. (Berita Harian.2/2/1962:1)

The formation of Malaysia which combines the Malay Peninsula, Singapore, North Borneo (Sabah), Brunei and Sarawak (Hashim, 1991:218-219) This Malaysian idea is opposed by Dr. Burhanuddin and other radical figures such as Ahmad Boestamam, Prof. Zulkifi Muhammad and Dato Onn who are in the Dewan Rakyat. This opposition is due to the fact that the proposed formation of Malaysia is not in line with what they struggle before independence. Their bag of Malaysian concept to be implemented by the Federal Government should be based on the concept of Malay Raya. (Parliamentary Debates, 1963:990) In order to empower the Malays, the concept of Malay Raya must be revived. Dr. Burhanuddin suggested that Tunku Abdul Rahman include the Philippines and Indonesia in the notion of Malaysia and Tunku should first discuss it with Indonesian and Filipino leaders. After a lengthy process of debate, almost 2 years was forced to take a tragic confrantation with Indonesia under the leadership of President Sokerno. Then it was also faced with the political turmoil of the Philippines led by the President of Macapagal. Political maturity owned by Tunku Abdul Rahman managed to overcome this problem as good as possible. It is a successful political coalition that has been successfully deployed. Then the formation of Malaysia be officially realized on 16 September 1963.

But Singapore was removed from Malaysia after some unpleasant acts of the Federal Government of Malaysia. This tragedy is a sad episode because the interconnected collaboration does not last long. It only takes 2 years and 9 days only, from 31 August 1963 to 9 August 1965.

"An Act to made provision fot the government of Singapore consequent oh her becoming an independent and sovereign republic separate from and independent of Malaysia.

Be it enacted by the President with the advice and consent of the Parliment of Singapore, as follow:-

1. This Act may be cited as the Republic of Singapore Independence Act, 1965 , and shall be deemed to have come into operationon the 9th day og August, 1965(hereinafter in this Act reffered to as "Singapore Day"). 
2. In this Act, unless it is otherwise provided or the context otherwise requires-

$$
\begin{array}{r}
\text { "Head of State" means the President of Singapore; } \\
\text { "Legislature" or "Legislature of Singapore" means the President } \\
\text { and the Parliment of Singapore; } \\
\text { "Singapore" means the Republic of Singapore." }
\end{array}
$$

(Singapore Government Gazette Bills Supplement.13/12/1965:3)

The concurrence of Singapore between Malaysia and Singapore officially ended on August 9, 1965 and was born a republican state. While Singapore did not last long in Malaysia's ideas but Malaysia's ideas remained solid until today.

\section{Barisan Nasional Political Consensus}

The General Election on May 10, 1969 led to The May 13, 1969 Tragedy. It became the highlight of the issue of racial unity in Malaysia. This is due to the significant economic gap and racist attitude that thickened among Malaysians at that time. The election results were shocking to all parties in particular the PERIKATAN. This was the first time the government party loss majority in the general election. The victory parade by the opposition parties sparked racial issues among the multiracial society. Their irresponsible actions and extreme provocations invited hatred among the multiracial people. The uncontrollable situations resulted in racial riot.

Once again, the leadership of PERIKATAN formulated unity among Malaysians. The biggest success of PERIKATAN was to successfully combine the opposition parties and the government. It was indeed a significant political alliance in the history of Malaysia's politics under the leadership of Abdul Razak Hussein's, whereby two parties namely GERAKAN and the Parti Islam SeMalaysia (PAS) joined together under BARISAN NASIONAL in 1974.

\section{BARISAN ALTERNATIF Political Consensus (BA) 1999}

The excellence of BARISAN NASIONAL in governing the country was something undeniable. The opposition was still forming a formula of co-operation among them. The tragedy of Dato Seri Anwar Ibrahim being dismissed from the post of Deputy Prime Minister and UMNO Deputy President created an opportunity for the opposition parties to make political co-operation. Dato Seri Anwar Ibrahim was arrested and was being imprisoned for 6 years. This injustice was considered worst in the Malaysian political episodes. This tragedy burst a mass movement led by PAS through the formation of the Gerakan Keadilan Rakyat Malaysia (GERAK). (Shaharuddin Badaruddin dan Mohammad Syazwanuddin.2017:79) Dato Seri Anwar Ibrahim's sacking led to the establishment of the Parti Keadilan Nasional (PKN) in 1999. During the launching ceremony of the Parti Keadilan Nasional on April 4, 1999, Dato' Seri Anwar Ibrahim claimed; "The new dawn in Malaysia's politics has emerged and the establishment of this KeADILan is a manifestation of the dawn." (http//:www.partikeadilan.org./pelancaran/utus.anwar040499.htm. I.) 
GERAK, led by PAS, received the support of various parties including political parties and NGOs, resulting in the formation of the opposition party, the BARISAN ALTERNATIF. In the 11th General Election, it was a surprise to many parties as Terengganu was conquered by BARISAN ALTERNATIF, while Kelantan continues to remain under PAS. The commencement of the BARISAN ALTERNATIF was quite a weak bond because of PAS's unwillingness to compromise on the issue of making Malaysia an Islamic Country, something that has never been approved by the Democratic Action Party (DAP). However with the aim to defeat BARISAN NASIONAL, they still agreed to form BARISAN ALTERNATIF. But after the 1999 elections, with PAS's big victory and the defeat of DAP's two major leaders, Lim Kit Siang and Karpal Singh in their area, the tensions and differences of opinions had risen so on 21 September 2001, the DAP announced its withdrawal from BARISAN ALTERNATIF.

\section{PAKATAN RAKYAT Political Consensus 2008-2015}

The release of Dato Seri Anwar Ibrahim from prison on September 16, 2004 gave a fresh start to the opposition parties and boosted the political world of Malaysia. He was determined to oppose all forms of tyranny and injustice, starting with the reform movement from 1998 to Tun Dr. Mahathir Mohammad resignation from leading Malaysia. After he was free from prison he continued to drive political work to liberate Malaysia's politics from the abuse of power and the elimination of corrupt practices that are critical enough nowadays (Sani, 2008:7)

Observing the political realities and the fact of the multiracial society in Malaysia, then the opposition continued to strive to form a new political alliance. The revival of the opposition contract with a more realistic political party arrangement had formed PAKATAN RAKYAT (PR) with the slogan of Building the New Malaysia. PAKATAN RAKYAT which consisted of PKR, PAS and DAP was successfully formed with some reduction in their policy and differences between them. Temporary political compromise was obtained by PAS agreeing not to enter Malaysia as an Islamic Country in a joint manifesto and DAP would not include Malaysian Malaysia struggle. With a one-to-one strategy, a mutual agreement to create an election seat was achieved. The formation of PAKATAN RAKYAT was officially announced on April 1, 2008.

The PAKATAN RAKYAT leadership, led by three leading figures, Anwar Ibrahim, Nik Abdul Aziz Nik Mat and Lim Kit Siang agreed to go against bribery, political integrity and the country's economic governance which was seen to be more lame. The 2008 General Election showed PAKATAN RAKYAT'S excellence. Then the victory of Anwar Ibrahim winning the P44-Permatang Pauh election opened a new political dimension of Malaysia. This atmosphere gave a big shock to Umno and BARISAN NASIONAL'S party. On August 2008, Dato' Seri Anwar Ibrahim swore as a member of parliament in the House of Commons and then on August 30, 2008, he once again took the oath as Opposition Leader in the House of Commons.(Mohammad Redzuan Othman.2009:133) The spirit of reform and Makkal Sakti were strong in the people. The winds of change were increasingly vibrant when on January 17, 2009, once again PAKATAN RAKYAT under his leadership managed to seize the P36-Kuala Terengganu seat through the election. A series of parliamentary elections showed that PAKATAN RAKYAT which was under his leadership won with a record of 7-0, making the BARISAN NASIONAL 
desolate, as of September 2009. Then the 2013 general election showed a severity in Malaysia's politics when popular votes favored PAKATAN RAKYAT, 51.8\%. while the BARISAN NASIONAL government only got $48.2 \%$ of the popular votes. In fact, it was already twice that the BARISAN NASIONAL lost parliamentary majority (Besar, 2014:28)

However, the change of the leadership of the SeMalaysia Islamic Party (PAS) and the loss of PAS's political pillar, the death of Tuan Guru Nik Abdul Aziz Nik Mat in 2014 made PAS lose direction. The arrest and prosecution of sodomy 2 against Dato Seri Anwar Ibrahim made him arrested, tried and imprisoned. PAKATAN RAKYAT lost 2 major leaders. This loss makes PR lose direction and a common goal in their political affiliation. The PAS leadership which was under the guidance of Haji Abdul Hadi Awang, was seen as unfriendly with PKR and DAP leadership. This scenario called for a PR split in 2015. PR split and the emergence of PAKATAN HARAPAN, a coalition of opposition parties such as the Malaysian United Indigenous Party (PPBM), PKR, DAP and AMANAH under the leadership of Tun Mahathir Muhammad are seen as another Malaysian political collaborative effort involving the multiracial society in Malaysia .

\section{Conclusion}

Political consensus is a social contract between its affiliates. Political understanding and tolerance is done by every member so that the ultimate goal of this agreement is achieved. In this case, the primary goal is to achieve independence, to gain citizenship and to guarantee the harmony of living together in an independent multiracial country. The post-independence political consensus goal is focusing on the well-being of Malaysians, as well as the transparency of the government and equal economic opportunity that can be enjoyed by all Malaysians while maintaining the harmony and prosperity of the country. Hence, each party seeks to prove its ability in political coordination to be accepted as the ruler of Malaysia.

In conclusion, indeed, multi-racial political co-operation is a matter of undeniable importance in the multiracial society, especially in Malaysia. The crucial question is how this agreement is beneficial to all Malaysians by taking into account the position of the Malays as the native Malaysians and the non-Malays as Malaysians. The issue of unity is often warmed when there are changes in the political landscape. Racial issues are raised by politicians for the sake of individual interests. The unity of the race is being denied to get back the fading support. It is supposed that politicians and political parties research and do some post mortem by referring to the long history of multi-racial political cooperation in Malaysia. In fact, history teaches the meaning of maturity. Hence history should be used as guidance, lessons learned and teaching for the sake of maintaining the prosperity and unity of Malaysians.

\section{References}

Adam, R. (1994). Ahmad Boestamam: Satu Bibliografi Politik. Kuala Lumpur. Dewan Bahasa dan Pustaka.

Adam, R. (1999). Sumbanganmu Dikenang. Kuala Lumpur. Dewan Bahasa dan Pustaka. 
Badaruddin, S. \& Shaharuddin, M.S. (2017). Islam, Demokrasi dan Politik Bangkangan di Malaysia. Shah Alam. Institut Darul Ehsan.

Besar, J.A. "Pilihan Raya Umum (PRU) 2013 di Malaysia: Suatu Analisis 'tsunami politik bandar" dlm GEORAFIA online. Malaysia Journal of Society and Space 10(28-38).@ 2014. ISSN 21802491.

Boestamam, A. (1972). Merintis Jalan ke Punchak. Kuala Lumpur. Dewan Bahasa dan Pustaka.

Burhanuddin A.H. (1956). Falsafah Kebangsaan Melayu, Tak Kan Melayu Hilang Di Dunia. Pustaka Semenanjung. Bukit Mertajam.

C0537/2140/136697 Secret HQ Malaya Command, Fortnightly Intelligence Review No. 61 Malay Affairs.

Exposition To The Amended Draft of the New Constitution For Malayan Drawn Up by Representatives of The PUTERA and The AMCJA, Arkib Negara Malaysia. Kuala Lumpur.

Fail UMNO/SUA 154/56- Fail Setiausaha Agong UMNO.

Fail UMNO/SUA No. 28A/1957. Testament Amanah Politik Perikatan, Cadangan-cadangan Penyata Reid dan syor perlembagaan Persekutuan Tahan Melayu. Kuala Lumpur. Arkib Negara Malaysa.

Hashim, Y. (1991). Tunku: Idealisme Dalam Kenangan. Pulau Pinang. Yayasan Bumiputera.

Ibrahim, M.A. (2004). GAGASAN Bangsa Malayan yang BERSATU 1945-57. Bangi. Penerbitan Universiti Kebangsaan Malaysia.

Othman, I. (2000). Sejarah Malaysia 1800-1963. Kuala Lumpur. Utusan Publications.

Othman, M.R. (2009). Permatang Pauh Pilihan Raya Kecil Ogos 2008. Shah Alam. KARISMA.

Parliamentary Debates. 1963. Dewan Ra'ayat (House of Representatives) bertarikh 15/8/1963.

Official Report. Volume V. No. 9. Kuala Lumpur. Parlimen Malaysia.

Saat, I. (2010). "Peranan Politik Suara Rakyat 1945-1948". DIm. Jurnal Kemanusiaan 17(2010), 65-89. Universiti Sains Malaysia. Penang.

Saat, I. (2015). Radikalisme Melayu Perak 1945-19970. Pulau Pinang. Universiti Sains Malaysia.

Sani, R.A. (2008). Failed Nation? Concerns of A Malaysian Nationalist. Petaling Jaya. Stategic Information and Research Development Centre.

Singapore Government Gazette Bills Supplement published by Authority. No.1. Monday, December 13, 1965. Singapore. Arkib Negara Singapore.

Stockwell, A.J. (1979). "British Policy and Malay Politics During The Malayan Union Experiment19421948," Malaysian Branch of the Royal Asiatic Society Monograph No.8 (MBRAS), Kuala Lumpur.

Sulaiman, A.N. (1988). “Aliran Kiri di dalam Politik Perkauman Malaya / Malaysia”. In JEBAT 16. Jurnal Jabatan Sejarah. Bangi. Universiti Kebangsaan Malaysia. 